\title{
Development of Equations for Estimating Greenhouse Gas Emisions from the Son La Hydropower Reservoir
}

\author{
Nguyen Thi The Nguyen ${ }^{1}$, Pham Van Hoang ${ }^{2}$, Nguyen Manh Khai ${ }^{3, *}$ \\ ${ }^{I}$ Water Resources University, Tay Son, Dong Da, Hanoi, Vietnam \\ ${ }^{2}$ Union of Science and Technology Vietnam, Xuan Dinh, Tay Ho, Hanoi, Vietnam \\ ${ }^{3}$ VNU University of Science, 334 Nguyen Trai, Thanh Xuan, Hanoi, Vietnam
}

Received 17 April 2017

Revised 28 April 2017; Accepted 28 June 2017

\begin{abstract}
Emissions of greenhouse gases such as $\mathrm{CO}_{2}$ and $\mathrm{CH}_{4}$ from artificial reservoirs, especially wide lakes in the tropics as the Son La hydropower reservoir, are leading to global warming. $\mathrm{CO}_{2}$ and $\mathrm{CH}_{4}$ gases in hydropower reservoirs are caused by the decomposition of organic matter in the lakes. In this study, regression analysis was used for estimating the relationships among water quality parameters measured at the Son La hydropower reservoir and the fluxes of greenhouse gas emissions from the reservoir. The regression analysis was also applied to develop regression equations predicting emissions of greenhouse gases from the lake. Results of study showed that the $\mathrm{CO}_{2}$ emission from the Son La hydropower reservoir could be predictable from several water quality parameters of which 4 main factors are temperature, DO, alkalinity andpH. The amount of $\mathrm{CH}_{4}$ emission from the Son La hydropower reservoir has solid relationships with 3 main factors, including temperature, $\mathrm{COD}$ and $\mathrm{pH}$. The regression equations predicting $\mathrm{CO}_{2}$ and $\mathrm{CH}_{4}$ with the correlation coefficient of 0.93 and 0.92 have been tested with real data and gave the good results. Since, they could be introduced in reality.
\end{abstract}

Keywords: Greenhouse gas, hydropower reservoirs, water quality, regression equation.

\section{Introduction}

Energy sources which are generated from burning fossil fuel provide about $68 \%$ of global electricity in 2007 and are responsible for most of the anthropogenic greenhouse gas emissions to the atmosphere (accounts for approximately $40 \%$ [1]). Compared to fossil fuels, hydropower has been considered an attractive renewable energy source with the advantage of being less

\footnotetext{
${ }^{*}$ Corresponding author. Tel.: 84-913369778

Email: khainm@vnu.edu.vn

https://doi.org/10.25073/2588-1094/vnuees.4102
}

harmful in terms of greenhouse gas emissions. Currently, hydroelectric power meets about $16 \%$ of the power supply of the world [2]. For countries which are dependent on hydroelectric energy, this kind of enerry souce accounts for 90\%. Previously, hydroelectric energy are not considered as greenhouse gas emissions. However, recent studies showed that hydropower reservoirs could produce more carbon into the atmosphere than natural systems, especially in the first twentyyears after flooding [3]. This is mainly due to the usually excessive availability of decomposable organic matter in hydroelectric reservoirs. Not only 
large amounts of soil and terrestrial vegetation are flooded by damming rivers, but terrestrial organic matter derived from land erosion is continuously flushed into reservoirs as well. The usually high water residence time in reservoirs as compared to rivers, combined with high inorganic nutrient inputs, favors organic matter decomposition and, thus, the production of two major greenhouse gases - carbon dioxide $\left(\mathrm{CO}_{2}\right)$ and methane $\left(\mathrm{CH}_{4}\right)$. The amount of $\mathrm{CO}_{2}$ and $\mathrm{CH}_{4}$ emitted varies (a) among reservoirs (as function of drainage basin characteristics, reservoir morphology, climate, etc.); (b) within reservoirs (along longitudinal gradients from the tributaries to the dam, before and after the dam, etc.); and (c) over time (with reservoir aging, seasonally, daily, with changes in anthropogenic activities in the drainage basin, and with dam operation depending on energy needs and precipitation regime) [4]. Attempts to estimate the amounts of $\mathrm{CO}_{2}$ and $\mathrm{CH}_{4}$ emitted to the atmosphere should consider such variability which makes it a complex task. Today, there are at least 45,000 large hydroelectric reservoirs operating in the world [5]. The area of those lakes in the world is estimated at about $350.000 \mathrm{~km}^{2}$ [5]. The lakes which have large storage capacity need to be examined the impact on global warming.

The ever increasing global energy demand and the concern about the changes in environment have lead to an urge to assess the hydropower 'footprint' in terms of greenhouse gas emissions to the atmosphere. Since the early 90's the role of hydroelectric reservoirs as sources or, as the opposite, sinks of greenhouse gases has rapidly become a global topic of investigation. The first studies of greenhouse gas fluxes from reservoirs focused on hydroelectric generation because it was, and still is, widely viewed as a carbon-free source of energy [6]. This view likely originated because before 1994, there were no data available on $\mathrm{CO}_{2}$ and $\mathrm{CH}_{4}$ emissions from reservoirs, even though it was well known that oxygen depletion resulting from active decomposition of flooded organic matter was common in waters of newly constructed reservoirs. The first discussion of greenhouse gas emissions from reservoirs pointed out that greenhouse gas production per unit of power generated [6]. Then, there were many studies of greenhouse gas fluxes from reservoirs located in Canada [6], Brazil, Panama and French Guiana. Later, reservoirs in Finland, USA and Switzerland, China were studied. In the world until 2012, there were at least 85 research reports which focused on greenhouse gas from hydropower reservoirs [7].

In recent years, Vietnam has been facing growing manifestations of climate change. The natural conditions and especially the human activities including hydropower reservoirs have been caused impacts on the process of climate change. Following the Convention of the United Nations Framework on Climate Change (UNFCCC), Vietnam has established the National Communications (NCs) and Biennial Update Reports (BURs), including national inventory results on greenhouse gas emissions. Greenhouse gas emissions in Vietnam are estimated by following fields: energy, industrial processes, agriculture, land use changes and agricultural land use (LULUCF) and waste. So far, there is no official result for the inventory of greenhouse gas emissions in the field of hydropower.

The Son La hydroelectric reservoir, which is the largest one in Vietnam, has a catchment area of $43.760 \mathrm{~km}^{2}$. It is also the largest reservoir in the field of capacity in Southeast Asia. To date, the Son La hydropower plant has been put into operation for about 5 years. Therefore it is necessary to access the possibility of greenhouse gas emissions from the reservoir and to set environmental management measures.

From the above requirements, this study was conducted to evaluate the possibility of greenhouse gas emissions and to develop equations for predicting the greenhouse gas emissions of $\mathrm{CO}_{2}$ and $\mathrm{CH}_{4}$ from the Son $\mathrm{La}$ hydropower reservoir. The research contributes to clarify the forecasting method of greenhouse gas emissions based on basic water quality 
parameters in the Son La hydropower reservoir as well as other lakes located in the tropical areas. Currently, water quality monitoring is carried out periodically at hydropower reservoirs and it is done more favorably than that of $\mathrm{CO}_{2}$ and $\mathrm{CH}_{4}$. Thus the results of the study will help to take full advantage of periodically measured results of water quality following the Environmental Protection Law No. 55/2014 / QH13 2014 at the hydropower reservoirs to predict $\mathrm{CO}_{2}$ and $\mathrm{CH}_{4}$ emissions without continuous monitoring of those gases.

\section{Study area and methods}

\subsection{Study area and object}

The Son La hydropower plant is located at It Ong commune, Muong La district, Son $\mathrm{La}$ province. After seven years of construction, the Son La hydropower reservoir was inaugurated on December 23, 2012. The scale of the reservoir is as follows: the normal water level is $215 \mathrm{~m}$, the dead water is $175 \mathrm{~m}$, the installed capacity is $2,400 \mathrm{MW}$, the average power output is 9429 million $\mathrm{kWh}$ annually. The total reservoir capacity is 9260 million $\mathrm{m}^{3}$, the useful capacity is 6504 million $\mathrm{m}^{3}$. The catchment area of $43760 \mathrm{~km}^{2}$ is located in three provinces of Son La, Dien Bien, Lai Chau. The lake has the largest width of about $1.5 \mathrm{~km}$ and $120 \mathrm{~km}$ in length from the dam at the town of It Ong, Muong La district, Son La province to back up upstream at Lai Chau province. Diagram of the Son $\mathrm{La}$ hydropower reservoir is presented in Figure 1.

This paper focuses on $\mathrm{CO}_{2}$ and $\mathrm{CH}_{4}$ gases which are two major ones standing at the top of the list of greenhouse gases on the Earth. Besides, fundamental water quality parameters monitored periodically in the Son $\mathrm{La}$ hydropower reservoir related to greenhouse gas emissions are also taken into consideration.

\subsection{Methods of study}

\subsubsection{Methods of sampling, sample} preservation and determination of water quality

Sample collection, preservation and analysis of surface water quality carried out under the guidance of national technical regulations. The water quality parameters were analyzed including temperature, $\mathrm{pH}$, TDS, conductivity, alkalinity, DO, COD, total nitrogen, $\mathrm{PO}_{4}{ }^{3-}$. The water samples were collected at six locations as shown in Figure 1, in which the sampling locations $\mathrm{C} 1, \mathrm{C} 2, \mathrm{C} 3, \mathrm{C} 5$ are the effluents into the reservoir, $\mathrm{C} 4$ is in the middle of the reservoir and C6 is after the Son La dam. Sampling periods are the dry seasons (March) and the rainy seasons (August) in the years 2014 and 2015. The analysis was conducted at the laboratory of the Centre for Environmental Research, Institute Meteorology, Hydrology and Environment.

\subsubsection{Sampling and determining methods of} the greenhouse gases

Fluxes of greenhouse gases from water surfaces can be quantified using a number of techniques [8]. In this study, floating static chambers have been used to estimate the diffusive flux of $\mathrm{CO}_{2}$ and $\mathrm{CH}_{4}$ from the surface of reservoirs by calculating the linear rate of gas accumulation in the chambers over time.

$\mathrm{CO}_{2}$ gas is collected following the method of air sampling in the sealed chamber Rolston (1986) [9], and is determined by applying the method under the ISO 5563-199. The size of $\mathrm{CO}_{2}$ collecting box is as follows: the box diameter is $30(\mathrm{~cm})$, the box height is $20(\mathrm{~cm})$, of which the submerged part is $7 \mathrm{~cm}$, the useful height is $13 \mathrm{~cm}$. The air in the sealed container was sucked by the Kimoto -HS7 machine with the rate of 2 liters of gas per minute and is absorbed by $\mathrm{Ba}(\mathrm{OH})_{2}$ solution. The air through the air receiver without $\mathrm{CO}_{2}$ continues to return the sealed container to push the remaining $\mathrm{CO}_{2}$ in the box. Sampling time is 10 minutes. $\mathrm{CO}_{2}$ samples were collected at the same places and time with the water quality samples. After $\mathrm{CO}_{2}$ is absorbed by $\mathrm{Ba}(\mathrm{OH})_{2}$ solution, excess $\mathrm{Ba}(\mathrm{OH})_{2}$ is titrated by oxalic acid. 


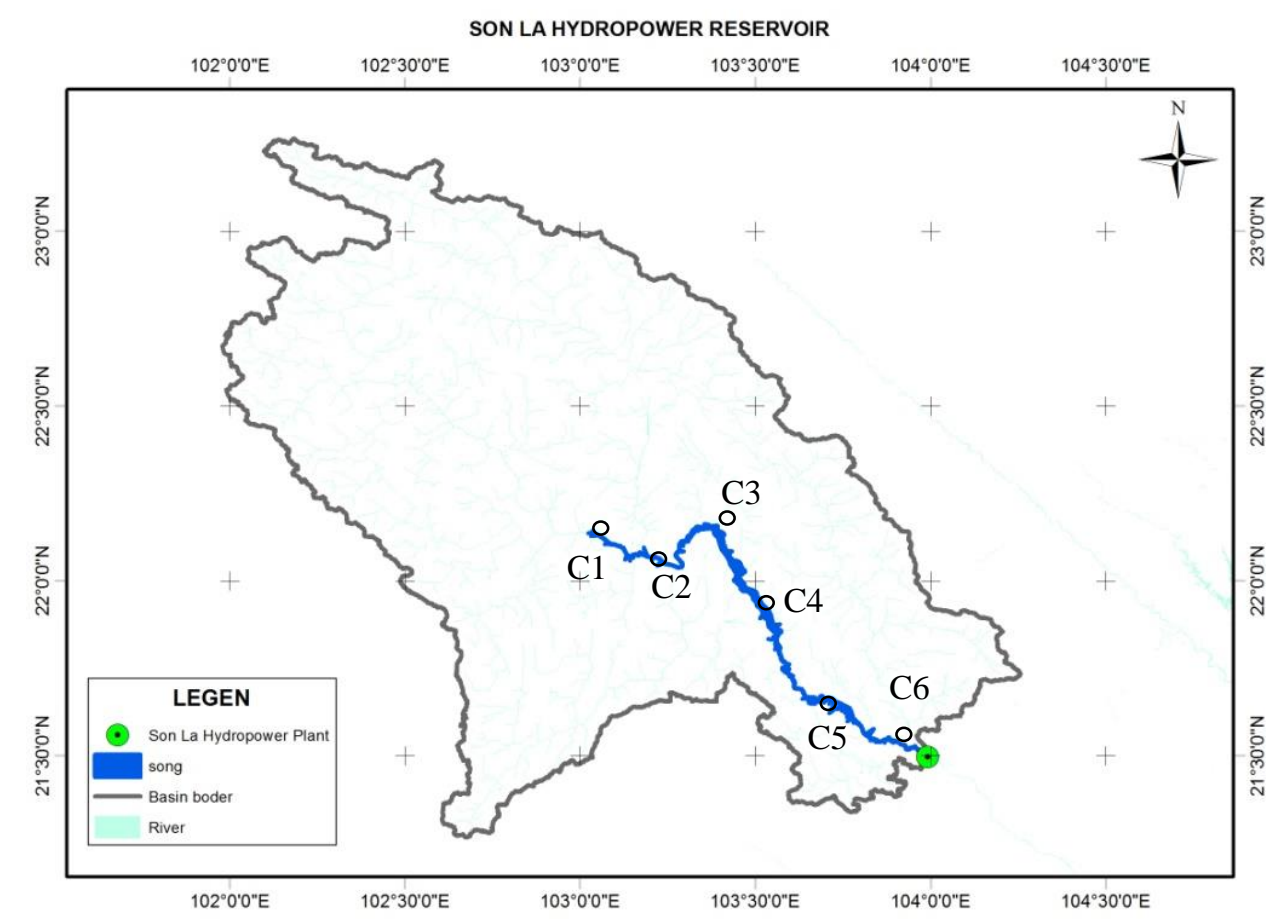

Figure 1. Location map of Son La hydropower reservoir and water quality collection points

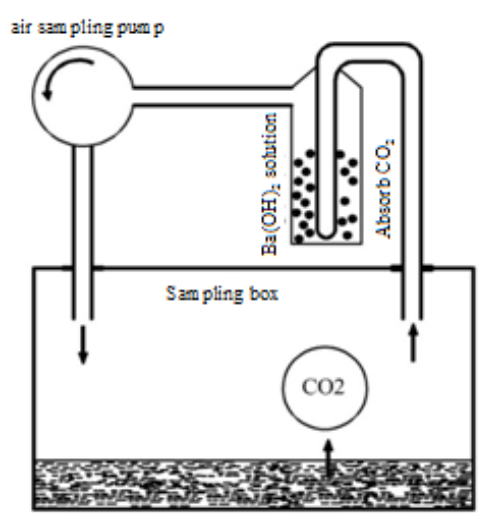

Figure 2. Sampling principle diagram of $\mathrm{CO}_{2}$.

$\mathrm{CH}_{4}$ gas is also collected following the method of air sampling in the sealed chamber Rolston (1986) [10]. The $\mathrm{CH}_{4}$ collection box has the same size with the $\mathrm{CO}_{2}$ collection box. The sealed chamber which has a determined area had been placed on the surface of the reservoir. The air was sucked by the air cylinder chamber at the time of 0 minute (in order to determine the initial amount of $\mathrm{CH}_{4}$ contained in sealed container), 10 minutes and 20 minutes. Gas samples were saved in neutral glass tubes with the volume of $20.0 \mathrm{ml}$. The air samples were analyzed by using gas chromatography machine GC17A and FID detector of which the carrier gas is $\mathrm{N}_{2} . \mathrm{CH}_{4}$ samples were collected and analyzed at the same places and times as the water samples.

\subsubsection{Regression analysis technique}

The regression analysis technique was used to develop the equations describing the relationships between water quality factors and $\mathrm{CO}_{2}, \mathrm{CH}_{4}$ gas emissions from the Son $\mathrm{La}$ hydropower reservoir. This study method has been being applied for forecasting in many fields like hydrological factors, climate, environment, economy ... The accuracy of the technique depends on the length of the data string. Multivariate regression equations have a general following form [9]: 
$\mathrm{Y}_{\mathrm{k}}=\beta+\beta_{1} \mathrm{X}_{1}+\beta_{2} \mathrm{X}_{2}+\beta_{3} \mathrm{X}_{3}+\beta_{4} \mathrm{X}_{4}+\ldots .+$ $\beta_{\mathrm{k}} \mathrm{X}_{\mathrm{k}}$; Correlation coefficient $\mathrm{R}^{2}$

Where:

- $\mathrm{Y}_{\mathrm{k}}$ : dependent variable, $\mathrm{k}$ : number of independent variables

- $\mathrm{X}_{\mathrm{i}}$ : independent variable

- $\beta$ freedom coefficient, $\beta_{1,2, . . \mathrm{k}}$ : separate regression coefficients or slopes.

Correlation coefficient, $\mathrm{R}^{2}$, is alway from 0 to 1 . It is useful because it gives the proportion of the variance (fluctuation) of one variable that is predictable from the other variable. It is a measure that allows us to determine how certain one can be in making predictions from a certain model/graph. The correlation has low level when $0 \leq \mathrm{R}^{2}<0.3$, average level when $0,3 \leq \mathrm{R}^{2}$ $<0.5$, quite close level when $0,5 \leq \mathrm{R}^{2}<0.7$, high level when $0,7 \leq R^{2}<0.9$, very high level when $0,9 \leq R^{2} \leq 1$.

In this study, dependent variables are $\mathrm{CO}_{2}$ and $\mathrm{CH}_{4}$, while 9 independent variables are temperature, $\mathrm{pH}$, TDS, conductivity, alkalinity, $\mathrm{DO}, \mathrm{COD}$, total nitrogen, $\mathrm{PO}_{4}{ }^{3-}$. Input data to develop the linear regressions of $\mathrm{CO}_{2}$ and $\mathrm{CH}_{4}$ are monitoring results of water quality at 6 locations in 4 periods in 2014 and 2015. In addition, periodically measurement data of water quality in the Son La reservoir in 5 years is also used for the study.

\subsubsection{Data processing methods}

The Excel and Eviews Software were used to statistically analyze the water quality results and to access links between greenhouse gas emissions in Son La and the water quality factors.

\section{Results and discussions}

3.1. Current status of water quality and greenhouse gas emissions from the Son La hydropower reservoir in the years 2014, 2015

The results of water quality analysis showed that most indicators of water quality in rainy season had higher concentrations than those in dry season. The reason could be that during rainy season, higher water flows from the upstream of the basin carried more sediment, pollutants into the reservoir. Moreover, people living inside the basin took advantage of submerged land for crop cultivation, especially planting cash crops. When rainy season came, the agricultural waste and manure left over on this part submerged made the concentration of pollutants in the reservoir increasing. Compared to the National technical regulation on surface water quality (QCVN 08: 2008/BTNMT), water quality in the Son La reservoir was acceptable for purposes of irrigation, waterway or others.

The average $\mathrm{CO}_{2}$ values emitting from the Son La hydropower reservoir in 2014 and 2015 fluctuated from 161.64 to $238.83 \mathrm{mg} / \mathrm{m}^{2} /$ day. The total $\mathrm{CO}_{2}$ emission from the whole surface of the reservoir was about 36207.36 to 53497.92 tons/day, corresponding to 0.62 to 0.92 tons $\mathrm{CO}_{2} / \mathrm{MW}$. Compared to those values in some research in the world, for example the research on the Wohlen reservoir in Switzerland (the $\mathrm{CO}_{2}$ value at the first year of operation was $1558 \pm 613 \mathrm{mg} / \mathrm{m}^{2} /$ day, dropped to $276 \pm 57$ $\mathrm{mg} / \mathrm{m}^{2} /$ day at the $3 \mathrm{rd}$ year) and the Lungern reservoir in Switzerland (the $\mathrm{CO}_{2}$ value was $136 \pm 353 \mathrm{mg} / \mathrm{m}^{2} /$ day [11]), the level of $\mathrm{CO}_{2}$ emission from the Son La hydropower reservoir after 5 years operation was moderate.

The average $\mathrm{CH}_{4}$ value measured at the Son La hydropower reservoir in 2014 and 2015 ranged from $3.22-5.30 \mathrm{mg} / \mathrm{m}^{2} /$ day. The total $\mathrm{CH}_{4}$ emission from the reservoir ranged from 153.44 to 1232 tons/day, corresponding to 0.0148 to 0.0213 tons $\mathrm{CH}_{4} / \mathrm{MW}$. Compared to some research findings on hydropower reservoirs (for example in China the $\mathrm{CH}_{4}$ emissions in some lakes and reservoir were $2.88 \pm 1.44 \mathrm{mg} / \mathrm{m}^{2} /$ day, the value for the Three Gorge reservoir in China was about $7.2 \pm 2.4$ $\mathrm{mg} / \mathrm{m}^{2} /$ day [12]), the level of $\mathrm{CH}_{4}$ emission from the Son La hydropower reservoir was also moderate. 
3.2. Evaluation of the relationships between greenhouse gas emissions with water quality parameters

3.2.1. The correlations between $\mathrm{CO}_{2}$ and the water quality parameters

The correlation between $\mathrm{CO}_{2}$ and the water quality parameters is shown in Figure 3 and
Table 1. The results show high correlations between $\mathrm{CO}_{2}$ values and temperature $\left(\mathrm{R}^{2}=\right.$ $0.67)$, DO $\left(R^{2}=0.55\right)$, alkalinity $\left(R^{2}=0.65\right)$, $\mathrm{pH}\left(\mathrm{R}^{2}=0.61\right)$. The correlation between $\mathrm{CO}_{2}$ and conductivity is very low $\left(\mathrm{R}^{2}=0.06\right)$. This means that two variables have no relationship with each other. Therefore, the emission of $\mathrm{CO}_{2}$ from the reservoir is affected primarily by temperature, $\mathrm{DO}$, alkalinity and $\mathrm{pH}$.

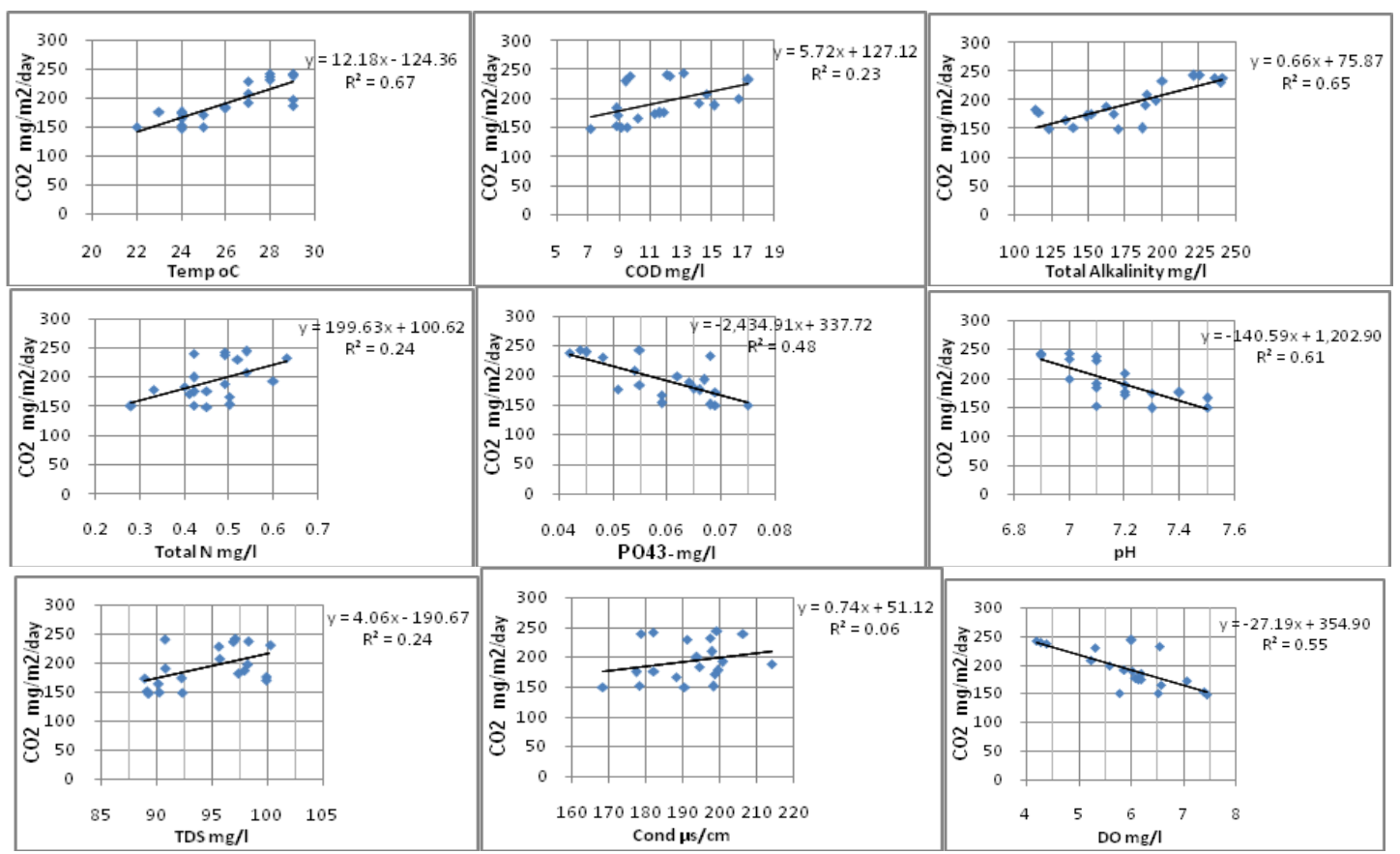

Figure 3. Correlations between $\mathrm{CO}_{2}$ and temperature, $\mathrm{pH}$, TDS, conductivity, alkalinity, $\mathrm{DO}, \mathrm{COD}$, total nitrogen and $\mathrm{PO}_{4}{ }^{3-}$.

Table 1. Correlation between $\mathrm{CO}_{2}$ and some water quality parameters

\begin{tabular}{llll}
\hline TT & Correlation & Function & $\mathrm{R}^{2}$ \\
\hline 1 & $\mathrm{CO}_{2}$ and temperature & $\mathrm{y}=12,18 \mathrm{x}-124,36$ & 0,67 \\
2 & $\mathrm{CO}_{2}$ and DO & $\mathrm{y}=-27,19 \mathrm{x}+354,90$ & 0,55 \\
3 & $\mathrm{CO}_{2}$ and COD & $\mathrm{y}=5,72 \mathrm{x}+127,12$ & 0,23 \\
4 & $\mathrm{CO}_{2}$ and alkalinity & $\mathrm{y}=0,66 \mathrm{x}+75,87$ & 0,65 \\
5 & $\mathrm{CO}_{2}$ and total nitrogen & $\mathrm{y}=44,24 \mathrm{x}+97,05$ & 0,24 \\
6 & $\mathrm{CO}_{2}$ and $\mathrm{PO}_{4}^{3-}$ & $\mathrm{y}=199,63 \mathrm{x}+100,62$ & 0,48 \\
7 & $\mathrm{CO}_{2}$ and $\mathrm{pH}$ & $\mathrm{y}=-140,59 \mathrm{x}+1202,90$ & 0,61 \\
8 & $\mathrm{CO}_{2}$ and TDS & $\mathrm{y}=4,06 \mathrm{x}-190,67$ & 0,24 \\
9 & $\mathrm{CO}_{2}$ and conductivity & $\mathrm{y}=0,74 \mathrm{x}+51,12$ & 0,06 \\
\hline
\end{tabular}

$\mathrm{CO}_{2}\left(\mathrm{mg} / \mathrm{m}^{2} /\right.$ day), temperature $\left({ }^{\circ} \mathrm{C}\right), \mathrm{DO}(\mathrm{mg} / \mathrm{l})$, alkalinity $(\mathrm{mg} / \mathrm{l})$, total nitrogen $(\mathrm{mg} / \mathrm{l}), \mathrm{PO}_{4}{ }^{3-}(\mathrm{mg} / \mathrm{l}), \mathrm{pH}, \mathrm{TDS}(\mathrm{mg} / \mathrm{l})$ and conductivity $(\mu \mathrm{s} / \mathrm{cm}$.) 


\subsubsection{The correlations between $\mathrm{CH}_{4}$ and} the water quality parameters

The correlation coefficients $\mathrm{R}^{2}$ of the dependent variable $\mathrm{CH}_{4}$ and some water quality indicators are shown in Table 2 and Figure 4.
The results show high levels of correlation between $\mathrm{CH}_{4}$ and temperature $\left(\mathrm{R}^{2}=0.6\right)$, $\mathrm{COD}$ $\left(\mathrm{R}^{2}=0.57\right), \mathrm{pH}\left(\mathrm{R}^{2}=0.58\right)$. Therefore, the emission of $\mathrm{CO}_{2}$ in the reservoir is affected primarily by temperature, $\mathrm{COD}, \mathrm{pH}$.

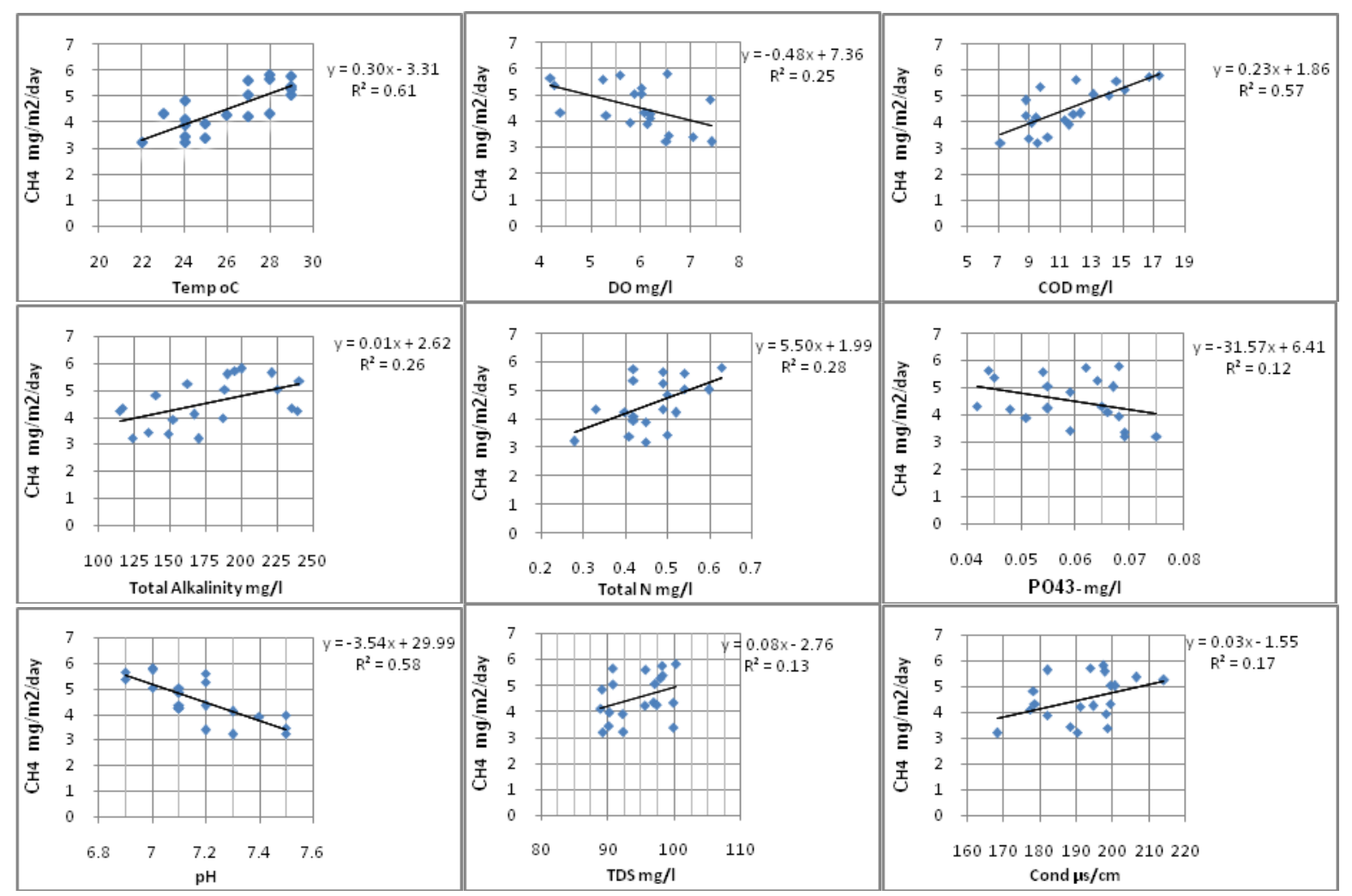

Figure 4. Correlation betweens $\mathrm{CH}_{4}$ and temperature, $\mathrm{pH}$, TDS, conductivity, alkalinity, $\mathrm{DO}, \mathrm{COD}$, total nitrogen and $\mathrm{PO}_{4}{ }^{3-}$.

Table 2. Correlation between $\mathrm{CH}_{4}$ and some water quality parameters

\begin{tabular}{llll}
\hline TT & Correlation & Funtion & $\mathrm{R}^{2}$ \\
\hline 1 & $\mathrm{CH}_{4}$ and temperature & $\mathrm{y}=0,30 \mathrm{x}-3,31$ & 0,61 \\
2 & $\mathrm{CH}_{4}$ and DO & $\mathrm{y}=-0,48 \mathrm{x}+7,36$ & 0,25 \\
3 & $\mathrm{CH}_{4}$ and COD & $\mathrm{y}=0,01 \mathrm{x}+2,62$ & 0,57 \\
4 & $\mathrm{CH}_{4}$ and alkalinity & $\mathrm{y}=0,01 \mathrm{x}+2,62$ & 0,26 \\
5 & $\mathrm{CH}_{4}$ and total nitrogen & $\mathrm{y}=5,50 \mathrm{x}+1,99$ & 0,28 \\
6 & $\mathrm{CH}_{4}$ and $\mathrm{PO}_{4}{ }^{3-}$ & $\mathrm{y}=-31,57 \mathrm{x}+6,41$ & 0,12 \\
7 & $\mathrm{CH}_{4}$ and $\mathrm{pH}$ & $\mathrm{y}=-3,54 \mathrm{x}+29,99$ & 0,58 \\
8 & $\mathrm{CH}_{4}$ and $\mathrm{TDS}$ & $\mathrm{y}=0,08 \mathrm{x}-2,76$ & 0,13 \\
9 & $\mathrm{CH}_{4}$ and conductivity & $\mathrm{y}=0,03 \mathrm{x}-1,55$ & 0,17 \\
\hline $\mathrm{O}_{2}\left(\mathrm{mg} / \mathrm{m}^{2} /\right.$ day $)$, temperature $\left({ }^{\circ} \mathrm{C}\right), \mathrm{DO}(\mathrm{mg} / \mathrm{l})$, alkalinity $(\mathrm{mg} / \mathrm{l})$, total nitrogen $(\mathrm{mg} / \mathrm{l})$,
\end{tabular}
$\mathrm{PO}_{4}{ }^{3-}(\mathrm{mg} / \mathrm{l}), \mathrm{pH}, \mathrm{TDS}(\mathrm{mg} / \mathrm{l})$ and conductivity $(\mu \mathrm{s} / \mathrm{cm})$. 
3.3. Development of predictive equations of $\mathrm{CO}_{2}$ and $\mathrm{CH}_{4}$ emissions from the Son $\mathrm{La}$ hydropower reservoir

\subsubsection{The predictive equation of $\mathrm{CO}_{2}$} emission

By applying the regression analysis technique and Eiview software, the forecasting equation of $\mathrm{CO}_{2}$ emissions is as follows:

$\mathrm{A} 1=367,62-3,04 \mathrm{~B}-9,508 \mathrm{C}+1,33 \mathrm{D}+$ $0.28 \mathrm{E}+85,17 \mathrm{~F}-662,45 \mathrm{G}-46,07 \mathrm{H}+2,55 \mathrm{I}$ (1)

$R^{2}=0,929$
Where $\mathrm{A} 1=\mathrm{CO}_{2}, \mathrm{~B}=$ temperature, $\mathrm{C}=$ $\mathrm{DO}, \mathrm{D}=\mathrm{COD}, \mathrm{E}=$ alkalinity, $\mathrm{F}=$ total nitrogen, $\mathrm{G}=\mathrm{PO}_{4}{ }^{3-}, \mathrm{H}=\mathrm{pH}, \mathrm{I}=\mathrm{TDS}$.

The correlation between the dependent variable $\mathrm{CO}_{2}$ and 8 independent variables (including temperature, DO, COD, alkalinity, total $\mathrm{N}, \mathrm{PO}_{4}^{3-}, \mathrm{pH}$ and total dissolved solids) has the maximum correlation coefficient $\mathrm{R}^{2}=$ 0,929 . The value of correlation coefficient value depends on the independent variables. When the number of independent variables decrees, the $\mathrm{R}^{2}$ also fells (see Table 3 ). This means that the predictive equation of $\mathrm{CO}_{2}$ emission should be based on a certain number of water quality parameters to give the best results.

Table 3. The changes in the correlation coefficients between $\mathrm{CO}_{2}$ with a number of water quality parameters

\begin{tabular}{lll}
\hline $\begin{array}{l}\text { Number of } \\
\text { parameters }\end{array}$ & Water quality parameters & $\mathrm{R}^{2}$ \\
\hline 8 & Temperature, alkalinity, $\mathrm{pH}, \mathrm{DO}, \mathrm{PO}_{4}{ }^{3-}$, total nitrogen, TDS, COD & 0,929 \\
7 & Temperature, alkalinity, $\mathrm{pH}, \mathrm{DO}, \mathrm{PO}_{4}{ }^{3-}$, total nitrogen, TDS & 0,924 \\
6 & Temperature, alkalinity, $\mathrm{pH}, \mathrm{DO}, \mathrm{PO}_{4}{ }^{3-}$, total nitrogen & 0,867 \\
5 & Temperature, alkalinity, $\mathrm{pH}, \mathrm{DO}, \mathrm{PO}_{4}{ }^{3-}$ & 0,856 \\
4 & Temperature, alkalinity, $\mathrm{pH}, \mathrm{DO}$ & 0,847 \\
3 & Temperature, alkalinity, $\mathrm{pH}$ & 0,808 \\
2 & Temperature, alkalinity & 0,750 \\
1 & Temperature & 0,670 \\
\hline
\end{tabular}

Table 4. The changes in the correlation coefficients between $\mathrm{CO}_{2}$ with a number of water quality parameters

\begin{tabular}{lll}
\hline $\begin{array}{l}\text { Number of } \\
\text { parameters }\end{array}$ & Water quality parameters & $\mathrm{R}^{2}$ \\
\hline 9 & $\begin{array}{l}\text { Temperature, } \mathrm{pH}, \mathrm{COD}, \text { total nitrogen, alkalinity, DO, conductivity, } \\
\text { TDS, } \mathrm{PO}_{4}{ }^{-}\end{array}$ & 0,917 \\
8 & Temperature, $\mathrm{pH}, \mathrm{COD}$, total nitrogen, alkalinity, DO, conductivity, TDS & 0,908 \\
7 & Temperature, pH, COD, total nitrogen, alkalinity, DO, conductivity & 0,861 \\
6 & Temperature, pH, COD, total nitrogen, alkalinity, DO & 0,857 \\
5 & Temperature, $\mathrm{pH}, \mathrm{COD}$, total nitrogen, alkalinity & 0,840 \\
4 & Temperature, $\mathrm{pH}, \mathrm{COD}$, total nitrogen & 0,839 \\
3 & Temperature, $\mathrm{pH}, \mathrm{COD}$ & 0,838 \\
2 & Temperature, $\mathrm{pH}$ & 0,680 \\
1 & Temperature & 0,612 \\
\hline
\end{tabular}




\subsubsection{The predictive equation of $\mathrm{CH}_{4}$} emission

By applying the same process with $\mathrm{CO}_{2}$, the forecasting equation of $\mathrm{CH}_{4}$ emission has the following form:

$\mathrm{A} 2=29,44-0,03 \mathrm{~B}+0,11 \mathrm{C}+0,20 \mathrm{D}+$ $0,00087 \mathrm{E}-1,24 \mathrm{~F}-21,76 \mathrm{G}-3,07 \mathrm{H}-0,09 \mathrm{I}+$ $0,028 \mathrm{~K}(2)$

$$
\mathrm{R}^{2}=0,917
$$

Where $\mathrm{A} 2=\mathrm{CH}_{4}, \mathrm{~B}=$ temperature, $\mathrm{C}=$ $\mathrm{DO}, \mathrm{D}=\mathrm{COD}, \mathrm{E}=$ alkalinity, $\mathrm{F}=$ total nitrogen, $\mathrm{G}=\mathrm{PO}_{4}^{3-}, \mathrm{H}=\mathrm{pH}, \mathrm{I}=\mathrm{TDS}, \mathrm{K}=$ conductivity.

The maximum correlation coefficient between the dependent variable $\mathrm{CH}_{4}$ and the 9 independent variable (including temperature, DO, COD, alkalinity, total $\mathrm{N}, \mathrm{PO}_{4}{ }^{3-}, \mathrm{pH}$, total dissolved solids and conductivity) is 0.917 . The reduction of number of water quality parameters makes the $\mathrm{R}^{2}$ decreasing (Table 4). Like $\mathrm{CO}_{2}$, the predictive equation of $\mathrm{CH}_{4}$ emission should be based on a certain number of water quality parameters to give the best results.

\subsection{Verification of the predictive equations of $\mathrm{CO}_{2}$ and $\mathrm{CH}_{4}$ emissions from the Son $\mathrm{La}$ hydropower reservoir}

In order to verify the predictive equations of $\mathrm{CO}_{2}$ and $\mathrm{CH}_{4}$ emissions, the equations (1) and (2) above are applied to calculate the amount of $\mathrm{CO}_{2}$ and $\mathrm{CH}_{4}$. The input data is the measured values of water quality in 4 stages in the years 2014, 2015 at 6 locations (Figure 1). The results of statistical analysis are presented in table 5 and figure 5. As can be seen in those table and figure, the predictive values of $\mathrm{CO}_{2}$ and $\mathrm{CH}_{4}$ emissions by the equations are slightly higher than the experimental values. The results show the same tendency as observed in nature. Therefore, they can be applied to estimate the greenhouse gas emissions from the Son La hydropower reservoir.

Table 5. Statistical analysis of fluxes of $\mathrm{CO}_{2}$ and $\mathrm{CH}_{4}$ at the Son $\mathrm{La}$ hydropower reservoir

\begin{tabular}{lllll}
\hline \multirow{2}{*}{ Parameters } & \multicolumn{2}{l}{$\begin{array}{l}\text { Values of } \mathrm{CO}_{2} \\
\left(\mathrm{mg} / \mathrm{m}^{2} / \text { day }\right)\end{array}$} & $\begin{array}{l}\text { Values of } \mathrm{CH}_{4} \\
\left(\mathrm{mg} / \mathrm{m}^{2} / \text { day }\right)\end{array}$ \\
\cline { 2 - 5 } & Measured & Calculated & Measured & Calculated \\
\hline Number of sample $(\mathrm{n})$ & 24 & 24 & 24 & 24 \\
Minimum value & 149,92 & 136,61 & 3,21 & 3,34 \\
Maximum value & 245,72 & 243,60 & 5,82 & 5,93 \\
Average value & 193,45 & 194,14 & 4,54 & 4,74 \\
Standard deviation & 33,85 & 32,70 & 0,87 & 0,83 \\
\hline
\end{tabular}

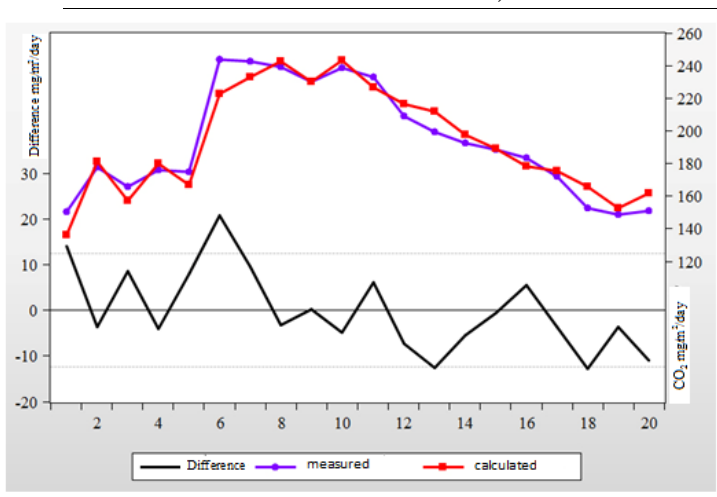

(a)

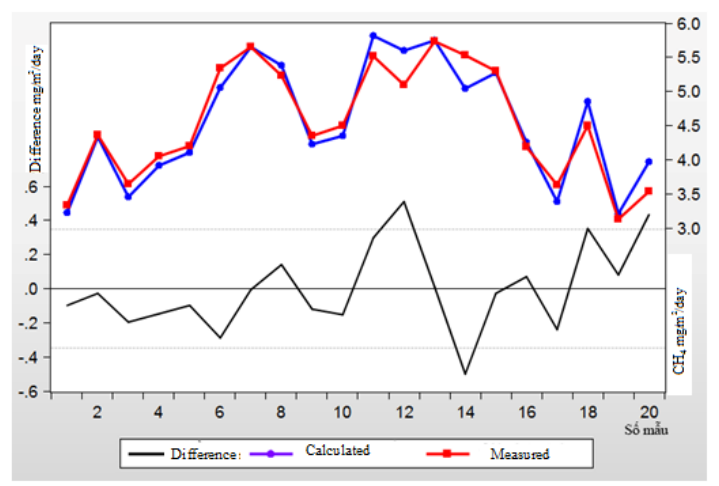

(b)

Figure 5. The calculated and measured fluxes of $\mathrm{CO}_{2}$ (a) and $\mathrm{CH}_{4}$ (b) at the Son La hydropower reservoir. 


\section{Conclusion}

The amounts of $\mathrm{CO}_{2}$ and $\mathrm{CH}_{4}$ greenhouse gas emissions from the Son La hydropower reservoir were average compared to other reservoirs in the world. $\mathrm{CO}_{2}$ emission from the Son La hydropower reservoir has relationships with several water quality parameters including 4 main factors: temperature, DO, alkalinity and $\mathrm{pH}$. The amount of $\mathrm{CH}_{4}$ emission from the reservoir also has relationships with several water quality parameters including 3 main factors: temperature, $\mathrm{COD}, \mathrm{pH}$. The regression equations predicting emissions of $\mathrm{CO}_{2}$ and $\mathrm{CH}_{4}$ in the Son La hydropower reservoir have been developed upon the actually measured values of water quality at the reservoir and give fairly consistent results with reality. Therefore, those equations can be used to estimate the amounts of $\mathrm{CO}_{2}$ and $\mathrm{CH}_{4}$ based on the periodic measurement of water quality. They also give a basis for making management measures to reduce greenhouse gas emissions from the reservoir in a better way.

\section{References}

[1] Huttunen, J.T.; Vaisanen, T.S.; Hellsten, S.K.; Heikkinen, M.; Nykanen, H.; Jungner, H.; Niskanen, A.; Virtanen, M.O.; Lindqvist, O.V.; Nenonen, O.S. \& Martikainen, P.J. (2002), "Fluxes of $\mathrm{CH}_{4}, \mathrm{CO}_{2}$, and $\mathrm{N}_{2} \mathrm{O}$ in hydroelectric reservoirs Lokka and Porttipahta in the northern boreal zone in Finland", Global Biogeochemical Cycles, Vol.16. No.1, 886.

[2] Guerin, F., and G. Abril (2007), "Significance of pelagic aerobic methane oxidation in the methane and carbon budget of a tropical reservoir", J. Geophys. Res. Biogeosci, 112.

[3] Abril, G., Guerin, F., Richard, S., Delmas, R., Galy-Lacaux, C., Gosse, P., Tremblay, A., Varfalvy, L., Dos Santos, M.A. \& Matvienko, B. (2005). "Carbon dioxide and methane emissions and the carbon budget of a 10-year old tropical reservoir (Petit Saut, French Guiana)", Global Biogeochemical Cycles, Vol.19. No.4.

[4] Raquel Mendonça, Nathan Barros, Luciana O. Vidal, Felipe Pacheco1, Sarian Kosten and Fábio Roland, (2012). "Greenhouse Gas Emissions from Hydroelectric Reservoirs: What Knowledge Do We Have and What is Lacking?", Greenhouse Gases - Emission, Measurement and Management, 55.

[5] Yang, L., F. Lu, X. Wang, X. Duan, W. Song, B. Sun, S. Chen, Q. Zhang, P. Hou, F. Zheng, Y. Zhang, X. Zhou, Y. Zhou, and Z. Ouyang (2012), "Surface methane emissions from different land use types during various water levels in three major drawdown areas of the Three Gorges Reservoir", J. Geophys. Res., 117.

[6] Rudd JWM, Harris R, Kelly CA, Hecky RE. (1993), "Are hydroelectric reservoirs significant sources of greenhouse gases?", Ambio, Vol. 22, 246.

[7] Barros, N.; Cole, J.J.; Tranvik, L.J.; Prairie, Y.T.; Bastviken, D.; Huszar, V.L.M.; Del Giorgio, P. \& Roland, F. (2011), "Carbon emission from hydroelectric reservoirs linked to reservoir age and latitude", Nature Geoscience, Vol. 4. No. 9, 593.

[8] Kelly CA. (1997), "Increases in fluxes of greenhouse gases and methyl mercury following flooding of an experimental reservoir", Environmental Science and Technology, Vol. 31, 1334.

[9] Rolston, D.E. (1986), "Gases flux”, In: A. Klute, editor, Methods of soil analysis. Part 1. Physical and mineralogical methods. SSSA Book Ser. 5. SSSA, Madison, WI. 1103.

[10] Amit Kumar, M.P. Sharma. (2014), "Impact of water quality on GHG emissions from Hydropower Reservoir", J. Mater. Environ. Sci., Vol 5 (1), 95.

[11] Diem, T.; Koch, S.; Schwarzenbach, S.; Wehrli, B. \& Schubert, C.J.. (2007), Greenhouse-gas $\left(\mathrm{CH}_{4}, \mathrm{~N}_{2} \mathrm{O}\right.$ and $\left.\mathrm{CO}_{2}\right)$ emissions from hydroelectric reservoirs in Switzerland.

[12] Ostrovsky, I., D. F. McGinnis, L. Lapidus, and W. Eckert (2008), "Quantifying gas ebullition with echosounder: the role of methane transport by bubbles in a medium-sized lake", Limnol. Oceanogr. Meth., Vol. 6, 105. 


\title{
Nghiên cứu xây dựng phương trình ước tính lượng khí nhà kính cho hồ thủy điện Sơn La
}

\author{
Nguyễn Thị Thế Nguyên ${ }^{1}$, Phạm Văn Hoàng ${ }^{2}$, Nguyễn Mạnh Khải ${ }^{3}$ \\ ${ }^{I}$ Trừ̀ng Đại học Thủy lợi, Tây Sơn, Đống Đa, Hà Nội, Việt Nam \\ ${ }^{2}$ Liên hiệp Khoa học và Công nghệ Môi truòng, Xuân Đỉnh, Tây Hồ, Hà Nội, Việt Nam \\ ${ }^{3}$ Truòng Đại học Khoa học Tự nhiên, ĐHQGHN, 334 Nguyễn Trãi, Thanh Xuân, Hà Nội, Việt Nam
}

Tóm tắt: Phát thải khí nhà kính như $\mathrm{CO}_{2}$ và $\mathrm{CH}_{4}$ từ các hồ chứa nhân tạo, đặc biệt là các hồ lớn ở vùng nhiệt đới như hồ thủy điện Sơn $\mathrm{La}$ đang dẫn đến sự nóng lên toàn cầu. $\mathrm{Khí} \mathrm{CO}_{2}$ và $\mathrm{CH}_{4}$ trong các hồ thủy điện sinh ra do sự phân hủy các chât hữu cơ trong lòng hồ. Trong nghiên cứu này, các thông số chất lượng nước như nhiệt độ, $\mathrm{DO}, \mathrm{COD}, \mathrm{TDS}, \mathrm{pH}$, tổng nitơ, phosphat, tổng độ kiềm, độ dẫn điện đo được tại hồ thủy điện Sơn La đã được phân tích hồi quy để tìm mối tương quan của chúng với lượng khí nhà kính phát thải từ hồ chứa này và từ đó xây dựng phương trình hồi quy dự đoán lượng khí nhà kính phát thải từ hồ. Kết quả phân tích hồi quy cho thấy lượng khí $\mathrm{CO}_{2}$ phát thải từ hồ thủy điện Sơn La có mối quan hệ với nhiều thông số chất lượng nước trong đó có 4 yếu tố chính là nhiệt độ, $\mathrm{DO}$, độ kiềm, $\mathrm{pH}$. Lượng khí $\mathrm{CH}_{4}$ phát thải từ hồ thủy điện Sơn La có mối quan hệ 3 yếu tố chính là nhiệt độ, $\mathrm{COD}, \mathrm{pH}$. Phương trình hồi quy dự đoán lượng khí $\mathrm{CO}_{2}$ và $\mathrm{CH}_{4}$ với hệ số tương quan là 0.93 và 0.92 đã được kiểm định với số liệu thực tế và cho kết quả khá tốt, từ đó có thể đưa vào áp dụng trong thực tế.

Tù khóa: Khí nhà kính, hồ thủy điện, chất lượng nước, phương trình hồi quy. 